\title{
Peran Konselor dalam Menghadapi Perilaku Temper Tantrum
}

\author{
David Ari Setyawan \\ Institut Agama Islam Negeri (IAIN) Kudus, Indonesia \\ davidarisetyawan@iainkudus.ac.id
}

\begin{abstract}
Abstrak
Anak usia 4-7 tahun merupakan masa untuk berkenalan dan belajar menghadapi rasa kecewa saat apa yang dikehendaki tidak dapat terpenuhi. Rasa kecewa, marah, sedih dan sebagainya merupakan suatu rasa yang wajar dan natural. Namun seringkali, tanpa disadari orang tua 'menyumbat' emosi yang dirasakan oleh anak. Misalnya saat anak menangis karena kecewa, orangtua dengan berbagai cara berusaha menghibur, mengalihkan perhatian, memarahi dan sebagainya demi menghentikan tangisan anak. Hal ini sebenarnya membuat emosi anak tak tersalurkan dengan lepas. Jika hal ini berlangsung terus menerus, akibatnya timbullah yang disebut dengan tumpukan emosi. Tumpukan emosi inilah yang nantinya dapat meledak tak terkendali dan muncul sebagai temper tantrum. Meluapkan kemarahan dengan tindakan - tindakan yang berbahaya dan menimbulkan cedera adalah salah satu bentuk tantrum agar anak mendapatkan apa yang ia inginkan. Perwujudan tantrum pada anak yang dapat menimbulkan resiko cedera tersebut dapat berupa menjatuhkan badan ke lantai, memukul kepala, atau melempar barang, hal ini diduga merupakan bentuk awal dari temper tantrum pada saat anak sudah mampu mengekspresikan rasa frustasinya. Jika temper tantrum telah terlanjur muncul dalam bentuk perilaku yang membahayakan dan berpotensi menimbulkan kerusakan, maka tindakan intervensi harus segera dilakukan. Semakin besar anak, tenaga juga semakin kuat dan akan semakin sulit bagi orang tua untuk mengendalikan atau mencegah tingkahlakunya yang tidak terkendali.
\end{abstract}

Kata kunci: Peran Konselor, Temper Tantrum. 


\begin{abstract}
Abstrak
THE ROLE OF COUNSELOR IN DEALING WITH TEMPER TANTRUM BEHAVIOR. Children aged 4-7 years is a time to get acquainted and learn to deal with disappointment when their desire cannot be fulfilled. Disappointment, anger, sadness, and so on is a natural feeling. However, often, parents unwittingly 'clog up' the emotions felt by the children. For example, when a child cries out in disappointment, parents in various ways try to entertain, distract, scold, and so on in order to stop the child's crying. This actually makes the children's emotions do not come out freely. If this continues, the result will be what is called the emotional pile. This pile of emotions can later explode out of control and appear as temper tantrum. Bursting anger with dangerous actions and causing injury is one form of tantrum so that children get what they want. The realization of the children's tantrum that can pose a risk of injury can be either dropping to the floor, hitting the head, or throwing things. These are considered as the first stage of temper tantrum when the children are able to express their frustration. If temper tantrums have already appeared in the form of harmful behaviors and have the potential to cause damage, then intervention must be done immediately. The bigger the child, the more powerful the energy is and the more difficult it will be for parents to control or prevent uncontrolled behavior.
\end{abstract}

Keywords: The role of counselor, Temper Tantrum.

\title{
A. Pendahuluan
}

Temper tantrum adalah salah satu dari sekian banyak kelainan pada kebiasaan-kebiasaan anak, sebagai suatu usaha untuk memaksakan kehendaknya pada orang tua, yang biasanya tampak dalam bentuk menjerit-jerit, berteriak dan menangis sekeras-kerasnya, berguling-guling di lantai dan sebagainya (Kartono, 1991: 13). Temper tantrum merupakan luapan emosi yang meledak-ledak dan tidak terkontrol. Kejadian ini seringkali muncul pada anak usia 15 bulan sampai 5 tahun. Tantrum terjadi pada anak yang aktif dengan energi yang melimpah (Hasan, 2011: 185). Temper tantrum merupakan ledakan amarah, ketakutan yang hebat dan iri hati yang tidak masuk akal Hurlock (1998: 115). Hal ini tampak mencolok pada anak-anak usia 2,5 sampai 3,5 dan 5,5 sampai 6,5 tahun. Ledakan amarah mencapai puncaknya antara usia dua dan empat tahun, setelah itu amarah berlangsung tidak terlampau lama. Temper tantrum merupakan gangguan tingkah 
laku yang terjadi pada anak usia tiga sampai tujuh tahun, gangguan ini ditandai dengan adanya suatu pola tingkah laku dissosial, agresif atau menentang yang berulang dan menetap (Maslim, 2003: 137). Temper tantrum merupakan ledakan emosi yang cukup kuat, disertai rasa marah, serangan agresif, ,menangis, menjeritjerit, menghentak-hentakkan kedua tangan dan kaki di lantai atau tanah (Chaplin, 2009:502). Temper tantrum merupakan perilaku destruktif dalam bentuk luapan yang bisa bersifat fisik (memukul, menggigit, mendorong), maupun verbal (menangis, berteriak, merengek) atau terus menerus merajuk Salkind (2002: 408).

Dari pengertian di atas dapat disimpulkan bahwa temper tantrum adalah suatu ledakan amarah yang sering terjadi pada anak usia tiga sampai enam tahun yang ditandai dengan tindakan menangis, menjerit-jerit, melempar benda, berguling-guling, memukul dan aktivitas destruktif lainnya. tantrum terjadi pada anak yang aktif dengan energi yang berlimpah. Tantrum dapat terjadi pada anakanak yang dianggap lebih sulit, dengan ciri-ciri sebagai berikut: (1) Memiliki kebiasaan makan, tidur, dan buang air besar tidak teratur, (2) Sulit menerima orang baru, (3) Lambat beradaptasi terhadap perubahan, (4) Suasana hati tidak stabil, (5) Mudah kesal, marah dan mudah terprovokasi, (6) Sulit dialihkan perhatiannya.

\section{B. Pembahasan}

Pola asuh orang tua adalah suatu metode disiplin yang diterapkan orang tua terhadap anaknya. Metode disiplin ini mempunyai dua konsep yaitu konsep negatif dan konsep positif, Hurlock (1998:82). Konsep positif, disiplin berarti pendidikan dan bimbingan yang lebih menekankan pada disiplin dan pengendalian diri. Konsep negatif, disiplin diartikan pengendalian dengan kekuasaan. Ini merupakan suatu bentuk pengekangan melalui cara yang tidak disukai dan menyakitkan. Dalam kasus ini memotret terjadi kesalahan konsep dalam pendidikan pola asuh orangtua kepada anak, sehingga mengakibatkan anak mengalami temper tantrum. Lebih jauh Hurlock menyebutkan bahwa fungsi pokok dari pola asuh orang tua adalah untuk mengajarkan anak menerima pengekanganpengekangan yang diperlukan dan membantu mengarahkan emosi anak ke dalam jalur yang berguna dan diterima secara sosial. Pola asuh orang tua akan mempengaruhi kepribadian dan perilaku anak (Dariyo, 2004: 97). Ada beberapa pola asuh orang tua yang dikenal dengan pola asuh otoriter, pola asuh demokratis dan pola asuh permisif Hurlock (1998:94). Dapat disimpulkan bahwa pola asuh adalah bentuk pengasuhan orang tua untuk menanamkan disiplin pada anaknya 
yang pada akhirnya akan membentuk kepribadian dan perilaku anak. Terdapat tiga tipe pola asuh yaitu pola asuh otoriter, pola asuh demokratis dan pola asuh permisif.

\section{Pola Asuh Otoriter}

Pengasuhan yang otoriter (authorian parenting) ialah suatu gaya membatasi dan menghukum yang menuntut anak untuk mengikuti perintahperintah orang tua dan menghormati pekerjaan dan usaha. Orangtua menuntut anak mengikuti perintah-perintahnya, sering memukul anak, memaksakan aturan tanpa penjelasan, dan menunjukkan amarah. Orang tua yang otoriter menetapkan batas-batas yang tegas dan tidak memberi peluang yang besar kepada anak-anak untuk berbicara atau bermusyawarah. Peraturan yang keras untuk memaksa perilaku yang diinginkan menandai semua jenis pola asuh yang otoriter Hurlock (2010: 93). Tekniknya mencakup hukuman yang berat bila terjadi kegagalan memenuhi standar dan sedikit, atau sama sekali tidak adanya persetujuan, pujian atau tanda-tanda penghargaan lainnya bila anak memenuhi standar yang diharapkan.Orang tua tidak mendorong anak untuk dengan mandiri mengambil keputusan-keputusan yang berhubungan dengan tindakan mereka. Sebaliknya, mereka hanya mengatakan apa yang harus dilakukan. Jadi anak-anak kehilangan kesempatan untuk belajar bagaimana mengendalikan perilaku mereka sendiri. Dengan cara otoriter, ditambah dengan sikap keras, menghukum dan mengancam akan menjadikan anak "patuh" di hadapan orang tua, tetapi di belakangnya ia akan menentang atau melawan karena anak merasa "dipaksa". Reaksi menentang bisa ditampilkan dalam tingkahlaku-tingkahlaku yang melanggar norma-norma lingkungan rumah, sekolah, dan pergaulan (Gunarsa, 2008:82). Efek pengasuhan ini, antara lain anak mengalami inkompetensi sosial, sering merasa tidak bahagia, kemampuan komunikasi lemah, tidak memiliki inisiatif melakukan sesuatu, dan kemungkinan berperilaku agresif (Soetjiningsih, 2012: 216). Anak dari orang tua yang otoriter sering kali tidak bahagia, ketakutan, minder ketika membandingkan diri dengan orang lain, tidak mampu memulai aktivitas, dan memliki kemampuan komunikasi yang lemah, serta sering berperilaku agresif (Santrock, 2002: 167).

\section{Pengasuhan Permisif}

Pengasuhan yang permisif ialah suatu gaya dimana orang tua sangat tidak terlibat dalam kehidupan anak. Anak mengembangkan perasaan bahwa aspekaspek lain kehidupan orangtua lebih penting daripada diri mereka. Biasanya pola asuh permisif tidak membimbing anak ke pola perilaku yang disetujui secara sosial 
dan tidak menggunakan hukuman. Orang tua membiarkan anak-anak meraba-raba dalam situasi yang terlalu sulit untuk ditanggulangi oleh mereka sendiri tanpa bimbingan atau pengendalian. Anak sering tidak diberi batas-batas atau kendali yang mengatur apa saja yang boleh dilakukan. Mereka diijinkan untuk mengambil keputusan sendiri dan berbuat sekehendak mereka sendiri (Hurlock, 2010: 93). Karena harus menentukan sendiri, maka perkembangan kepribadian anak menjadi tidak terarah. Pada anak tumbuh egosentrisme yang terlalu kuat dan kaku, dan mudah menimbulkan kesulitan-kesulitan jika harus menghadapi laranganlarangan yang ada dalam masyarakat.

Efek pengasuhan ini anak akan memiliki kendali diri yang buruk, inkopetensi sosial, tidak mandiri, harga diri rendah, tidak dewasa, rasa terasing dari keluarga, serta pada saat remaja akan suka membolos dan nakal (Soetjiningsih, 2012: 218). Anak dari orang tua yang permisif akan memiliki harga diri yang rendah, tidak dewasa, kesulitan belajar menghormati orang lain, kesulitan mengendalikan perilakunya, egosentris, tidak menuruti aturan, dan kesulitan dalam berhubungan dengan teman sebaya (Santrock, 2002: 168).

\section{Pengasuhan Demokratis}

Pola asuh demokratis mendorong anak-anak agar mandiri tetapi masih menetapkan batas-batas dan pengendalian atas tindakan-tindakan mereka. Musyawarah verbal yang ekstensif dimungkinkan dan orang tua memperlihatkan kehangatan serta kasih sayang kepada anak. Pengasuhan yang otoritatif diasosiasikan dengan kompetensi sosial anak. Metode demokratis menggunakan penjelasan, diskusi dan penalaran untuk membantu anak mengerti mengapa perilaku tertentu diharapkan, Hurlock (2010:93). Metode ini lebih menekankan aspek edukatif dari disiplin dari pada aspek hukumannya. Pada pola asuh ini menggunakan hukuman dan penghargaan, dengan penekanan yang lebih besar pada penghargaan. Hukuman tidak pernah keras dan biasanya tidak berbentuk hukuman badan. Hukuman hanya digunakan bila terdapat bukti bahwa anak-anak secara sadar menolak melakukan apa yang diharapkan dari mereka. Bila perilaku anak memenuhi standar yang diharapkan, orang tua yang demokratis akan menghargainya dengan pujian atau persetujuan orang lain. Dengan cara demokratis ini pada anak akan tumbuh rasa tanggungjawab untuk memperlihatkan sesuatu tingkahlaku dan selanjutnya memupuk rasa percaya dirinya. Anak akan mampu bertindak sesuai norma dan menyesuaikan diri dengan lingkungannya (Gunarsa, 2008:84). 
Efek pengasuhan demokratis, yaitu anak mempunyai kompetensi sosial percaya diri, dan bertanggung jawab secara sosial. Juga tampak ceria, bisa mengendalikan diri dan mandiri, berorientasi pada prestasi, mempertahankan hubungan ramah dengan teman sebaya, mampu bekerja sama dengan orang dewasa, dan mampu mengatasi stres dengan baik (Soetjiningsih, 2012: 217). Anak dari orang tua yang demokratis ceria, bisa mengendalikan diri dan mandiri, dan berorientasi pada prestasi, mereka cenderung untuk mempertahankan hubungan yang ramah dengan teman sebaya, bekerja sama dengan orang dewasa, dan bisa mengatasi stres dengan baik (Santrock, 2002: 167).

\section{Peran Konselor dalam Proses Konseling}

Pemberian konseling tidak hanya diberikan pada klien tetapi juga harus dilakukan pada orang tua. Hal ini dikarenakan konsep pola asuh orang tua juga menjadi dasar anak untuk dapat berkembang optimal sesuai dengan tugas perkembangannya. Disini konselor sangat berperan membantu mengarahkan dan mengembangkan potensi yang dimiliki anak. Dalam menangani anak yang mengalami temper tantrum ini konselor harus bekerja sama baik dengan pihak sekolah, keluarga, dan masyarakat. Konselor dapat membantu dalam hal: 1) Memberikan informasi kepada orang tua yang sedang kegundahan memiliki anak yang mengalami temper tantrum. Informasi yang diberikan berhubungan dengan diagnosisnya dan dukungan yang dapat diberikan oleh orang tua dalam membantu anaknya mencapai aktualisasi diri dan melakukan hal-hal sebagaimana petunjuk sekolah yang menanganinya, 2) Membantu mencapai dan mensugestikan respons emosional yang sesuai untuk mengurangi ketegangan yang mungkin ada antara orang tua, konselor maupun anak yang bersangkutan, 3) Membangun kelompok orang tua yang dapat memberi dukungan dan yang mengalami hal-hal yang kurang lebih sama, 4) Menjalankan sesi dan mengenalkan pola asuh dalam pendidikan keluarga, 5) Konselor sangat mampu mengatasi pikiran-pikiran negatif melalui konseling kelompok maupun individual. Demikian pula penjelasan bahwa seseorang dapat saja hebat dalam bidang tertentu, tetapi tidak demikian dalam hal lain.

Disini seorang konselor memberikan bantuan bukan hanya kepada orang tua anak yang mengalami temper tantrum tetapi juga terhadap anak yang bersangkutan. Jika diperlukan untuk melakukan proses konseling, karena mereka berbeda dengan teman-temannya yang lain. Anak tersebut sulit bergaul dengan teman-temannya, disini peran kita sebagai konselor dibutuhkan untuk memberikan anak tersebut dukungan bahwa kelebihan yang dimilikinya itu 
merupakan anugerah dari Tuhan, yang tidak semua orang memilikinya. Dan memberikan pemahaman bahwa setiap individu itu unik dan memiliki keunikannya masing-masing. Konselor juga wajib mengarahkan anak tersebut untuk memanfaatkan kelebihan yang dimilikinya dengan hal-hal yang positif dan berguna bagi pengembangan potensi nya.

Penelitian ini menggunakan metode penelitian kualitatif dengan desain studi kasus. Subyek penelitian ini terdiri dari subyek penelitian yang menjadi informan kunci yang dapat memberikan data yang dibutuhkan oleh peneliti, yakni dua anak usia dini yang berinisial GG dan berinisial AR, adapun subyek sekunder terdiri dari 3 orang kerabat dari GG dan AR. Peneliti menggunakan pendekatan kualitatif dikarenakan data-data yang didapatkan nantinya adalah data kualitatif berupa kata-kata atau tulisan tidak berbentuk angka dan untuk mengetahui serta memahami fenomena secara terinci mendalam dan menyeluruh. Data penelitian dikumpulkan dengan wawancara. Selanjutnya hasil penelitian dianalisis dengan pendekatan kualitatif model interaktif sebagaimana diajukan oleh Miles dan Hubermas, yaitu terdiri dari empat hal utama, yakni pengumpulan data, reduksi data, pemaparan data dan penarikan kesimpulan atau verifikasi (Sugiyono, 2009).

Hasil penelitian menunjukkan bahwa dari kedua subyek penelitian samasama mengalami temper tantrum. Jika subyek GG menghendaki sesuatu yang diinginkan selalu meluapkan emosinya dengan berteriak sangat kencang dan mengguling-gulingkan badannnya dilantai tanpa kontrol, sehingga mengkhawatirkan dapat melukai dirinya sendiri. Sedangkan subyek AR saat menginginkan sesuatu selalu yang diinginkan meluapkan emosinya dengan memukul apa yang ada didepannya, bahkan melempar apa yang ada disekitarnya. Hal ini tentu dapat berdampak pada tingkah laku yang kurang baik dan nantinya akan menjadi rekaman yang buruk ketika seseorang tumbuh kembang menjadi dewasa. Temuan dilapangan munculnya temper tantrum diawali dengan kesalahan cara orangtua berkomunikasi dan bersikap kepada anak. Sehingga secara umum kesalahan yang dilakukan orangtua kepada anak menjadikan anak kecewa, marah dan menangis. Hal ini juga didukung dengan pola asuh yang belum konsisten yang mengakibatkan anak tidak mampu menyesuaikan tugas perkembangannya dengan optimal. Hampir setiap anak mengalami temper tantrum dan umumnya hal ini terjadi pada hampir seluruh periode awal masa kanak-kanak (Hurlock, 1998: 114). Temper tantrum sering terjadi karena anak merasa frustasi dengan keadaannya, sedangkan ia tidak mampu mengungkapkan perasaannya dengan kata-kata atau ekspresi yang diinginkannya (Hasan, 2011: 187) 
Temper tantrum terjadi pada anak yang pemalu, penakut, dan sering cemas terhadap orang asing, Salkind (2002:408),. Keterlambatan dalam perkembangan bahasa, gangguan pendengaran, gangguan system syaraf pusat dapat menyebabkan temper tantrum. Lingkungan anak akan mempengaruhi intensitas dan frekuensi tantrum. Pada anak usia 2-3 tahun, tantrum terjadi karena anak usia tersebut biasanya sudah mulai mengerti banyak hal dari yang didengar, dilihat maupun dialaminya, tetapi kemampuan bahasa atau berbicaranya masih sangat terbatas (Hasan, 2011: 187). Berikut adalah beberapa faktor yang menyebabkan terjadinya temper tantrum (1) Terhalangnya keinginan untuk mendapatkan sesuatu; (2) Ketidakmampuan anak mengungkapkan diri; (3) Tidak terpenuhinya kebutuhan; (4) Pola asuh orang tua.; (5) Anak merasa lelah, lapar atau dalam keadaan sakit yang dapat menyebabkan anak menjadi rewel; (5) Anak sedang stress dan merasa tidak aman, Setiawani (2000:133). Beberapa penyebab temper tantrum adalah; (1) Masalah keluarga, keluarga yang tidak harmonis akan membuat anak kehilangan kehangatan keluarga, yang dapat mengganggu kestabilan jiwa anak; (2) Anak yang dimanja akan membuat anak dapat memanfaatkan orang tuanya; (3) Anak yang kurang tidur, kelelahan, memiliki tubuh dan keadaan fisik yang lemah akan membuatnya cepat marah.; (4) Masalah kesehatan, ketika anak mengalami kurang enak badan, ada masalah kesehatan atau tubuh cacat, semua yang mempengaruhi kekuatan pengendalian dirinya, atau hal yang tidak sesuai dengan dirinya, akan mudah membuat anak marah; (5) Masalah makanan, beberapa makanan dapat membuat anak peka atau alergi yang membuat anak menjadi kehilangan kekuatan untuk mengendalikan diri, seperti makanan yang mengandung zat pewarna atau pengawet, dan coklat; (6) Kekecewaan, saat anak menyadari keterbatasan kemampuan dirinya dalam menyatakan keinginannya dan tidak dapat melakukan sesuatu hal, membuat anak mudah marah; (5) Meniru orang dewasa, ketika melihat ada orang dewasa yang tidak dapat menyelesaikan atau menghadapi kesulitan, lalu marah-marah, ditambah di rumah orang tua dan di sekolah konselor juga mudah marah, akan membuat anak meniru mereka menjadi anak yang mudah marah. Aktivitas yang menimbulkan temper tantrum antara lain; (1) Rintangan terhadap gerak yang diinginkan anak, baik rintangan itu berasal dari orang lain atau dari ketidakmampuan diri sendiri, (2) Rintangan terhadap aktivitas yang sudah mulain berjalan, (3) Rintangan terhadap keinginan, rencana, dan niat yang ingin dilakukan anak, Hurlock (2010: 222).

Maka dapat disimpulkan faktor penyebab anak mengalami temper tantrum antara lain: (1) Faktor fisiologis, yaitu lelah, lapar atau sakit; (2) Faktor psikologis, 
antara lain anak mengalami kegagalan, dan orangtua yang terlalu menuntut anak sesuai harapan orangtua; (3) Faktor orangtua, yakni pola asuh; (4) Faktor lingkungan, yaitu lingkungan keluarga dan lingkungan luar rumah.

\section{Simpulan}

Temper tantrum adalah suatu ledakan amarah yang sering terjadi pada anak usia tiga sampai enam tahun yang ditandai dengan tindakan menangis, menjerit-jerit, melempar benda, berguling-guling, memukul dan aktivitas destruktif lainnya.

Faktor penyebab anak mengalami temper tantrum antara lain: (1) Faktor fisiologis, yaitu lelah, lapar atau sakit; (2) Faktor psikologis, antara lain anak mengalami kegagalan, dan orangtua yang terlalu menuntut anak sesuai harapan orangtua; (3) Faktor orangtua, yakni pola asuh; (4) Faktor lingkungan, yaitu lingkungan keluarga dan lingkungan luar rumah. Bentuk-bentuk perilaku temper tantrum adalah sebagai berikut: menangis dengan keras, menendang segala sesuatu yang ada di dekatnya, memukul benda, dirinya sendiri, maupun orang lain, membentur- benturkan kepala, melempar-lempar dan merusak barang, menghentak-hentakkan kaki, berteriak- teriak dan menjerit, membanting pintu, merengek, mengancam dan memaki.

Pola asuh orang tua sangat mempengaruhi setiap perilaku anak. Model pengasuhan orang tua akan membentuk suatu perilaku atau pengelolaan emosi yang berbeda-beda sesuai apa yang telah diajarkan oleh orang tua. Orang tua merupakan lingkungan pertama bagi anak yang sangat berperan penting dalam setiap perkembangan anak khususnya perkembangan kepribadian dan emosi anak. Sehingga peran konselor dalam membantu orangtua untuk mengatasi permasalahan temper tantrum sangat diperlukan melalui proses konseling yang lebih inten. 


\section{Daftar Pustaka}

Dariyo, Agoes. (2007). Psikologi Perkembangan Anak Tiga Tahun Pertama. Bandung: Refika Aditama.

Gunarsa, Singgih D. (2008). Psikologi Anak dan Remaja. Jakarta: PT BPK Gunung Mulia.

Hayes, Eileen. (2003). Tantrum. Jakarta: Erlangga

Hurlock, E.B. (1998). Psikologi Perkembangan Suatu Pendekatan Sepanjang Rentang Kehidupan. Jakarta: Erlangga.

Hagan, Jessica S. (2006). Mendidik Anak Memasuki Usia Prasekolah. Jakarta: PT. Prestasi Pustakaraya.

Hasan, Maimunah. (2011). Pendidikan Anak Usia Dini. Jogjakarta: Diva Press.

Indraswari, Ayunita. (2012). Perilaku Sosial Pada Kanak-Kanak Awal yang Mengalami Temper Tantrum (Studi Kasus di KB Permata Hati Desa Kebon Agung Kecamatan Kajen, Kabupaten Pekalongan). Skripsi Universitas Negeri Semarang

Ismaya, Y. (2010). Pengaruh Penggunaan Timeout Terhadap Penurunan Temper Tantrum Pada Usia Balita. Jurnal. Pekanbaru: PSIK UR.

Junita.T, Inneke. (2013). Gambaran Strategi yang Dilakukan Orang Tua dalam Menghadapi Tantrum pada Anak dengan Autism Spektrum Disorder. Jurnal.Pekanbaru.

Kartono, Kartini. (1991). Bimbingan Bagi Abak dan Remaja yang Bermasalah. Jakarta: CV. Rajawali.

Latipun. (2004). Psikologi Eksperimen Edisi II. Malang: UMM Press.

Pratisti, Wiwien Dinar. (2008). Psikologi Anak Usia Dini. Jakarta: PT Indeks.

Salkind, Neil J. (2002). Child Development. USA: Macmillan Reference.

Santrock, J.W. (2002). Life-Span Development: Perkembangan Masa Hidup (Edisi Kelima). Jakarta: Erlangga.

Setiawani, Mary Go. (2000). Menerobos Dunia Anak. Bandung: Yayasan Kalam Hidup.

Soetjiningsih, Christiana Hari. (2012). Perkembangan Anak. Jakarta: Prenada Media Group.

Sugiyono. (2009). Metodologi Penelitian Kuantitatif, Kualitatif dan R\&D. Bandung: Alfabeta.

Yusuf, H. Syamsu. 2011. Psikologi Perkembangan Anak dan Remaja. Bandung: Remaja Rosdakarya. 